Fecha de recepción: marzo 2015 Fecha de aceptación: junio 2015 Versión final: marzo 2016
Imagen, memoria y Nación. La historia del Perú en sus imágenes primigenias

Leopoldo Lituma Agüero *

Resumen: Luego de la Independencia, la construcción iconográfica devino en indispensable por la necesidad de educar en la Historia patria desde un punto de vista vernáculo. Sin embargo fueron extranjeros los primeros que se abocaron a la investigación y compendio de la historia patria desde sus orígenes. Aquellos textos, sin imágenes aún, se utilizaron en la incipiente educación peruana del siglo XIX.

A principios del siglo XX aparecieron los primeros textos escolares ilustrados, los cuales incorporaron imágenes tomadas de publicaciones foráneas, algunas de ellas con una visión europeizante. Otras publicaciones menos idealizadas ayudaron con sus dibujos y grabados a la historia visual del país, y cuando fueron incorporados a los libros para educación básica, ayudaron a crear un imaginario colectivo.

El presente artículo muestra algunas de las principales fuentes iconográficas que sirvieron para instruir a la población escolar de principios del siglo XX. Asimismo la investigación muestra cómo estas imágenes primigenias se tomaron como referente cierto en diversas situaciones de la historia del Perú y cómo éstas han influido en la (in) conciencia nacional; hechos corroborados por otras investigaciones sociológicas.

Palabras claves: iconografía - imaginario - historia - educación básica - Perú.

[Resúmenes en inglés y portugués en la página 135]

(*) Magister en Arte Peruano y Latinoamericano.

\title{
Introducción
}

El arte contribuye con sus representaciones a la conciencia histórica y a la idea de nación de un país. Aunque la búsqueda de la identidad nacional es un proceso de largo trayecto en el cual historiadores, intelectuales, arquitectos y diversos artífices culturales, van acrecentando el imaginario durante sucesivas generaciones; es cuando un país recién se gesta que la participación e influencia de los artistas es más resaltante dada la necesidad de producción de nueva iconografía que recuerde y perennice los hitos trascendentes en la construcción de la nueva nación.

Los tiempos posteriores a nuestra independencia son un claro ejemplo de ello; a pocos años de la emancipación, el pintor mulato José Gil de Castro pintó los célebres retratos de 
Simón Bolívar ${ }^{1}$, y más tarde hizo lo propio con el primer héroe nacional de aquella gesta libertaria: José Olaya. Ambas imágenes perduran hasta hoy volviéndose íconos y válidos referentes históricos de ambos personajes.

En los siguientes años nuevas pinturas fueron incrementando el arte peruano y, cuando las posibilidades técnicas lo permitieron, dichas imágenes se reprodujeron en los incipientes textos escolares a principios del siglo XX. Al hacerse masivas se incorporaron entonces en la memoria colectiva del peruano.

La iconografía plasmada en los libros fue captada, asimilada e ideologizada por miles de estudiantes. Aquellas imágenes perduraron por generaciones de escolares quienes experimentaron con ellas sentimientos no siempre coadyuvantes a la integración nacional, como veremos más adelante.

\section{Imagen y memoria}

Un siglo después de los postulados de Pestalozzi, quien había afirmado que no se debería enseñar nada que no se pueda ver, éstos se materializaron en la educación nacional con la publicación del libro Resumen de la Historia del Perú de Carlos Wiesse a principios del siglo XX que incorpora por primera vez muchos grabados, dibujos y fotos acompañando y reforzando los textos.

Desde su inicio, las imágenes en la educación escolar han debido tener primordial importancia en la trasmisión de ideología; y las primeras debieron incorporarse en el inconsciente colectivo con el paso de los años.

Un claro ejemplo de esta influencia se evidenció en 1969 cuando el artista Jesús Ruiz Durand creó, "basado en sus recuerdos infantiles", la imagen esquemática de Túpac Amaru que sería utilizada en el gobierno de Velasco Alvarado. Efectivamente, ante las continuas críticas a esta imagen, y al ser inquirido por su fuente, el artista confesó que no había consultado ninguna, pero que recordaba la clásica imagen del cacique cuzqueño que había visto en los textos escolares, al igual que todos los peruanos de aquél entonces ${ }^{2}$.

\section{Fuentes iconográficas para una historia visual del Perú}

La primera publicación que trata sistemáticamente la Historia del Perú aparece en 1860 gracias a la loable iniciativa personal de maestro español Sebastián Lorente quien en ese año publicó Historia Antigua del Perú. El texto, de casi 350 páginas, no contenía ningún dibujo o gráfico, sin embargo su importancia radica en ser el primero en su género y en haber mostrado metodológicamente nuestra historia, previa a la llegada de los españoles. Lo mismo sucedió con su segundo texto publicado en 1861 Historia de la Conquista del Perú de aproximadamente 500 páginas, el cual estaba dividido en diez libros que narraban desde el Descubrimiento del Perú hasta la Consumación de la Conquista.

Dado que estos dos libros no fueron escritos precisamente para un público escolar, Lorente escribiría otro en 1866, titulado Historia del Perú para uso de los colegios y las personas ilustradas, el cual compendiaba de una manera más didáctica la Historia del Perú. Años 
después haría lo propio con sus Primeras lecciones de Historia del Perú, publicado en 1872, aunque éste tampoco incluía lámina alguna.

En su Historia Antigua del Perú, Lorente se lamenta de no haber podido encontrar escritos anteriores que narraran verídicamente la historia de nuestro país encontrándose todo en una nebulosa que combinaba la historia con la fábula. En el prólogo Lorente se refiere varias veces a la gratuita fantasía que inundaba los pocos escritos sobre la historia antigua del Perú, aunque a decir verdad, sus textos, aunque menos sueltos a la imaginación, tampoco escapan a esta calificación.

A estos mitos probablemente contribuyeron las imágenes de dos libros fundamentales en la descripción de los hechos del nuevo mundo a propósito de su conquista: uno de ellos es la novela épica y moral de Marmontel Los Incas o la destrucción del Imperio del Perú, y el otro la Historia de la Conquista del Perú de William Prescott.

\section{Los Incas o la destrucción del Imperio del Perú}

El libro de Jean Francois Marmontel, publicado en París en 1777, tuvo sucesivas ediciones tanto en inglés como en castellano demostrando la gran acogida y difusión que tuvo. La primera en idioma español se editó en 1822. Esta obra fue "una especie de novela poética cuyo fundamento es la historia y la moral su fin", según Jean Francoise de La Harpe, dramaturgo y crítico francés del siglo XVIII.

Los Incas incorporan doce imágenes, todas ellas escenas románticas que evocan el valor y la nobleza en la representación de nuestros antepasados. Éstas reflejan, de un lado, la visión de Francia del siglo XVIII acerca del Perú antiguo, y además el poco conocimiento de nuestra cultura en la confluencia con la de los españoles, mostrando a nuestros antepasados incas en una extraña mezcla de indígena plumífero, con arcos y flechas, mobiliario y utensilios europeos, dentro de escenarios.

Los personajes son de tez blanca, proporciones clásicas, semidesnudos y ataviados con plumas cual indígenas de la América del norte, seguramente más cercanos al historiador francés. En todas las escenas los supuestos incas aparecen con un semblante digno denotando en ocasiones una postura ejemplificadora y en otras la desazón por las atrocidades cometidas por sus sojuzgadores españoles. Marmontel en su texto los hace poseedores de la verdad, la moral, el arrojo y la lucha por el amor ante las dificultades y acciones de los conquistadores españoles.

\section{Historia de la Conquista del Perú}

Otro texto fundacional es el de William Prescott, Historia de la Conquista del Perú de 1847 cuya primera edición castellana tenía tan solo una única ilustración en la que se representa a Francisco Pizarro con armadura en su cuerpo y un morrión con plumas en la cabeza. Seis años después, en la tercera edición de 1853 publicada en Madrid, incorporaron 30 grabados que muestran una civilización diferente a la occidental pero con importantes realizaciones culturales. 
Las imágenes del libro de Prescott perduraron por décadas y fueron tomadas como históricamente válidas e Incluso las podemos encontrar en el capítulo correspondiente a la síntesis histórica, preparada por Horacio Urteaga; libro conmemorativo El Perú en el primer centenario de su Independencia de 1922.

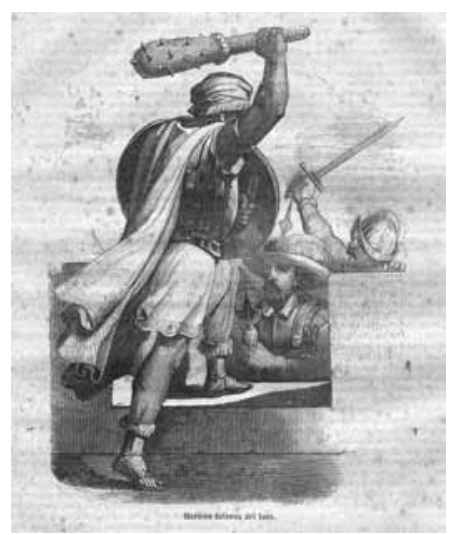

Figura 1. Mítica imagen de Cahuide defendiendo la fortaleza de Sacsayhuamán. El texto original menciona: "Heroica defensa del Inca”. Esta imagen sería incluida en numerosas publicaciones escolares escritas por diversos historiadores peruanos.

Aunque menos idealizadas pero con no pocos yerros históricos, las imágenes de este libro representan también un pasado imaginado en la mente de los ilustradores, todos ellos consagrados grabadores que laboraban en España por esos años y que colaboraban también con las revistas La Ilustración Española y Americana, y La Ilustración de Madrid. Sin embargo, como bien señala Alicia Mayer docente de la Universidad Nacional Autónoma de México, refiriéndose al libro Historia de la Conquista de México, del mismo autor y predecesor por cuatro años del texto referido a la conquista del Perú:

Este libro, como toda obra histórica, refleja juicios personales que son producto de una particular visión del mundo que, a su vez, se origina en una época determinada, y que ahora pueden resultarnos anacrónicos o falsos. Asimismo observamos una incapacidad de su parte para valorar el mundo indígena a la par del europeo. Por momentos parece difícil distinguir las fronteras entre la historia y la novela. (Mayer 2001, 449) 


\section{América, historia de su descubrimiento desde los tiempos primitivos hasta los más modernos}

Menos fantástica, correctamente ilustrada, e incluso, históricamente pertinente, fue una publicación de conmemoración de amplia difusión en América Latina y España publicada en Barcelona en 1892, a propósito del IV centenario del descubrimiento de América.

Para esa ocasión, el historiador y dibujante alemán Rodolfo Cronau, dirigió la importante colección que narra la historia de los pueblos primitivos (de norte, centro y sur de América). Cronau fue un gran investigador y eximio dibujante y su producción fue muy difundida en Latinoamérica; aún hoy es relativamente sencillo conseguir ejemplares en buen estado gracias a la calidad de la impresión. Los tomos están profusamente ilustrados y muchos de los dibujos son de la propia autoría de Cronau, quien copió de los objetos existentes en el Museo Etnográfico y de Instrucción Pública de Berlín, el Museo de Instrucción Pública de Leipzig y el Museo Etnográfico de Estocolmo; así como de fotografías y grabados de variada procedencia y de distinta época.

Todos las imágenes incorporadas por Cronau acompañan unos textos que narran respetuosamente los hechos y las realizaciones de las primeras culturas de América; muestran objetivamente sus herramientas, objetos y construcciones arquitectónicas, incluida la vestimenta y fisonomía de los nativos; sus referencias y fuentes son auténticas. No hay en sus palabras ni en sus retratos algo denigrante contra el indígena americano, y existe en general una valoración positiva de nuestro pasado prehispánico.

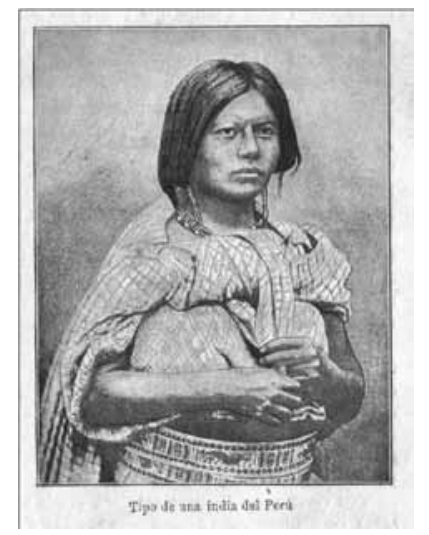

Figura 2. Cronau también se preocuparía en mostrar los diversos tipos de nativos de América con su respectiva vestimenta. En este caso el de "una india del Perú".

De nuestra cultura inca se expresa de la siguiente manera:

Todos trabajaban para el bien general; estaba severamente prohibida la holganza y no había pobres ni pordioseros, pues la comunidad tenía que 
atender a todos los ancianos o imposibilitados para el trabajo. Cada cual daba y recibía. Era, como dice muy acertadamente Ratzel, un estado socialista en el que muchísimas ocasiones tenía realización práctica cuanto han imaginado en Europa los más soñados utopistas respecto de la vida en familia de todo un pueblo. (Cronau, 1892, tomo II, 297, 298)

Los textos escolares que se publicarían años después en el Perú incorporaron varias imágenes de los libros de Prescott y Cronau, y alguna otra de Marmontel.

Estos tres libros fundacionales en la producción iconográfica del Perú Antiguo muestran finalmente, una visión idílica de nuestro pasado prehispánico que enaltece antes que disminuye a nuestros antepasados; en ellos se los considera seres humanos, aunque con una cultura diferente y curiosa para el europeo, pero no por ello plenos de realizaciones y aportes; lamentablemente estos valores no serían rescatados en nuestra propia producción historiográfica e ideológica, como sucedió en los textos escolares peruanos de comienzos del siglo XX.

Sus dibujos, grabados y pinturas fueron el inicio de la construcción de un imaginario iconográfico histórico e idílico que fuera complementado también por los artistas e intelectuales de la llamada "generación romántica peruana".

\section{Los primeros textos de Historia del Perú, apoyados en imágenes}

El libro fundacional que combinaba lo textual con lo visual con fines de enseñanza primaria, se editó en 1899 cuando Carlos Wiesse Portocarrero ${ }^{3}$ publicó su Resumen de la Historia del Perú dirigido a la instrucción en colegios, siendo uno de los primeros elaborado por un peruano ${ }^{4}$.

En este texto de pequeño formato $(17 \times 11 \mathrm{~cm}$.) y 306 páginas se incorporan grabados, dibujos y hasta fotograbados; novísima técnica gráfica que en el Perú tuvo sus inicios en 1898 con la incorporación de la foto del Sr. Luis Carranza en el diario El Comercio, del cual era su director en esos años. Esta publicación tuvo innumerables reediciones; no es exagerado decir que toda la juventud peruana instruida en las tres primeras décadas del siglo XX conoció la Historia del Perú a través de los textos de Carlos Wiesse, y que las imágenes de sus libros pasaron a formar parte de la memoria historiográfica del país.

Por primera vez se difundieron en un texto escolar las realizaciones arquitectónicas de nuestros antepasados tal cual se encontraban en esos años, es decir sin ningún trabajo de restauración; así también se mostraron algunos pocos ejemplos de nuestra cerámica prehispánica tomados del libro de Cronau, aunque sin mencionar la fuente.

Sin embargo, en este Resumen la gran mayoría de las imágenes y textos correspondían al Virreynato y la República. El llamado Perú Antiguo y la historia del Imperio de los Incas, es decir casi cinco mil años de historia, quedaban reducidas a tan solo seis páginas de las más de trescientas que tiene el texto.

Las láminas del texto de Carlos Wiesse también mostraban la segregación del indígena y de las otras razas no blancas en nuestro territorio, reducidos todos a una suerte de curiosidad, pero nunca considerados como parte integrante de la nación peruana. 
En la primera de estas láminas indígenas "posan" descalzos para el retrato del dibujante quien plasma una escena que los muestra en andrajos, revelando su miseria. Tres de los miembros de esta familia cargan tinajas que parecen revelar una tarea de aguador. Ninguno sonríe, más bien parecieran estar a la espera de alguna dádiva. El rostro de la mujer es el más expresivo y lastimero.

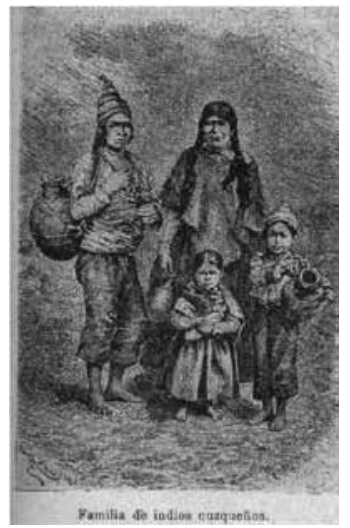

Figura 3. Una típica familia de “indios cuzqueños" incluida en el libro de Wiesse.

La siguiente lámina muestra a cuatro "Indios salvajes" de Tarma con sus utensilios de caza. Su vestimenta es típica de la selva y los collares de dos de ellos están hechos con colmillos de alguna fiera del lugar. Para Wiesse corresponden a un tipo de "indio no domado" del cual aún habían muchos en América y que "se conservaron y se conservan incólumes de todo contacto con las nuevas razas". (Wiesse, 1906, p. 138)

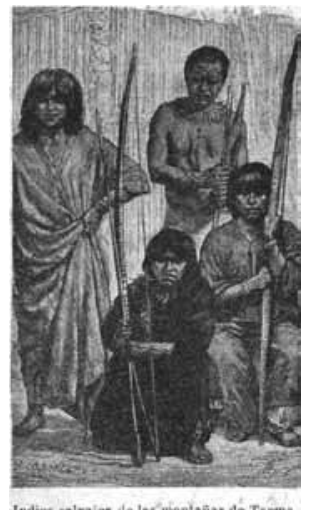

Figura 4. Otra de las pocas imágenes que muestran a nuestras etnias, consignada en los textos escolares de Carlos Wiesse. 
En otra página vemos el retrato de un joven indigente con "tipo de zambo" y expresión infantil, esta se incluye en el capítulo XXIX llamado El Perú Colonial. En el mismo capítulo se dice de esta raza que:

Es resistente cual ningún otro ser humano para el sol y los calores, las fiebres, los mosquitos y todas las plagas e incomodidades que matan al blanco $\mathrm{y}$ al indio en las hoyas de los grandes ríos sudamericanos, bravías y montaraces, que los debilitan en los vales de la costa peruana, en las otras costas ardientes del continente y en toda labor enervante y agotadora. (Wiesse, 1906, pp. 138 y 139)

Todas estas escenas están pensadas para retratar a nuestros indígenas y minorías étnicas (que en realidad son la mayoría) de un modo testimonial, pero menoscabados; antes que dignos como en las imágenes de Marmontel, Prescott o Cronau, lo que se muestra aquí es una desvalorización de lo indígena; y su condición de atraso y miseria (y de las razones de ello) no era siquiera comentada en los textos, más si mostrada en las imágenes.

Seguido de estos retratos de nuestras nacionalidades étnicas, se mostraban también a nuestros próceres, mandatarios y militares criollos siempre impecablemente uniformados, exhibiendo sus condecoraciones, y posando orgullosos para el fotógrafo o el pincel del artista.

De las 98 ilustraciones que tiene el libro Resumen de Historia del Perú de Carlos Wiesse, tan sólo 16 corresponde a nuestro pasado prehispánico, las restantes 82 muestran a españoles, criollos o hechos de la república hasta esos años.

Cabe aquí una reflexión: ¿qué pensamientos fluirían en los niños peruanos ante imágenes tan dispares en un mismo documento? Retratos que, por un lado, mostraban a nuestras razas autóctonas en un estado de casi indigencia, sin referencia ni mención en la vida ciudadana y, por el otro, la meticulosidad, el detalle y la cuidadosa postura fotográfica de los caudillos y dirigentes criollos del siglo XIX, así como de sus hechos y obras realizadas. Si, como hemos visto, ya existían y se utilizaban imágenes con una mejor disposición hacia el indígena ¿por qué no se las utilizó?

La respuesta a esta pregunta, que finalmente se refiere a la ideología de Wiesse, la encontramos en su mismo texto. Efectivamente en las primeras páginas de su libro Resumen de Historia del Perú, habla de nuestra raza nativa serrana indicando:

El carácter de los aborígenes quichuas-aimaraes, así como el de todos los americanos, se distingue por la lentitud de su excitabilidad y el poder de resistencia pasiva, unidos a un exterior tranquilo, una fuerza de sufrimiento y una prudencia general en los actos de la vida, llevados a su más alto grado. Esta pintura se completa observando el aire de tristeza reflexiva de su fisonomía, y aún la gran reserva y astuta desconfianza que gastan en su trato con los blancos. (Wiesse, 1906, p. 4)

Sufrimiento, tristeza, reserva y astuta desconfianza, es lo que justamente transparentan los personajes de las láminas que incorporó, por lo que se deduce que Wiesse necesitaba 
imágenes que sustentaran lo que escribía. Del mismo modo, cuando se refiere a Manco Cápac primero cita a Garcilaso de la Vega, quien pone en duda la leyenda acerca del origen divino luego escribe:

Otros escritores españoles refieren diversas leyendas, que no suministran datos para afirmarse la existencia real de Manco Cápac.

En todo caso, si este personaje existió, fue un reyezuelo jefe de bandas invasoras, que vivió en constantes reencuentros y combates por la posesión de los territorios de Pacaritambo y el Cuzco. (Id, p. 19)

Esta despectiva descripción de Manco Cápac aún continuará citándola hasta 1935, como se puede corroborar en la séptima edición del texto Historia del Perú Prehispánico de aquel año, dedicado exclusivamente a esta etapa inicial de nuestra historia.

Y acerca de las costumbres domésticas de nuestros antepasados dice:

Higiene.- Los indios, como hasta ahora, carecían de toda idea de higiene. Los Incas tenían baños, pero el común de los habitantes ni siquiera se lavaba. Las pestes encontraban por eso terreno preparado para sus estragos. (Id, p. 19)

Aquí citamos a Portocarrero y Oliart ${ }^{5}$ quienes desde su óptica sociológica coinciden con nuestras deducciones que parten de la iconografía:

Es como si Wiesse se sintiera aliviado de encontrar diferencias sociales y satisfecho de expresarlas, en tanto ello permitía considerar normal la situación del Perú en el momento en que él escribe, situación marcada por la desigualdad y la existencia de un abismo cultural entre grupos sociales. (Portocarrero y Oliar, 1989, p. 52)

\section{María Rosay, una historia olvidada}

Es recién en la segunda década del siglo XX que una educadora francesa llamada María Rosay ${ }^{6}$ brindó una perspectiva más justa de nuestra historia en sus textos escolares. De formación educadora, con estos volúmenes ella deseaba corresponder de algún modo al país que la había acogido.

Su libro Mi Primera Historia del Perú, cuya primera edición debe haber ocurrido hacia 1920, incorpora desde su carátula y contra carátula, elementos traídos de la iconografía del Perú Antiguo creando una ornamental y atractiva portada. El texto estaba profusamente ilustrado y sus imágenes buscaban mostrar un pasado preincaico e incaico pleno de magníficas realizaciones y avances en las técnicas de producción agrícola, textilería, geografía y orfebrería. 
Es sintomático que Rosay no utilizara el término "indígena" en su libro, sino el de "primitivos pobladores" al referirse a la época preincaica, y "antiguos peruanos" a los que corresponden a la época incaica.

\section{Conclusiones}

La producción de imágenes de la historia antigua del Perú surge en el siglo XVIII idealizada por escritores ajenos y lejanos a nuestras verdaderas circunstancias.

Las primeras fuentes iconográficas correspondientes al Perú fueron de producción foránea; sin embargo trataron benevolentemente a nuestros antepasados prehispánicos trasluciendo en sus imágenes virtudes tales como laboriosidad, dignidad, valentía, heroísmo; mientras que otras mostraban nuestros notables conocimientos en arquitectura, metalurgia, hidráulica, cerámica y textilería. Esto se constata principalmente en los libros de Willams Prescott (1847) y el compendio de Rodolfo Cronau (1892), y sus láminas deben reconocerse como parte integrante de la memoria visual del Perú.

El desconocimiento de nuestra realidad profunda a fines del siglo XIX y principios del XX no solo es atribuible a los estudiosos extranjeros, sino también a los intelectuales peruanos quienes continuaron sin entender y valorar a sus culturas ancestrales pre-suponiendo que los indígenas eran seres disminuidos y para los cuales no había que tenerles mayor interés ni cuidado.

Como bien lo había indicado el viajero norteamericano George Squier en su paso por el Perú entre los años 1863 y 1865: "En Lima son menos los que conocen Cuzco que Berlín, por cada capitalino que ha visitado Cuzco, cien han visitado Paris". (Squier, 1877, p. 455) Es recién a principios del siglo XX que las imágenes de nuestra historia comienzan a ser construidas y difundidas. Sin embargo los primeros textos escolares siguieron adoleciendo de una visión europeizante del mundo y no reconocieron ni valoraron a quienes eran la mayoría de habitantes de su país ni a los importantes logros que habían obtenido en diferentes campos de la cultura.

El Resumen de Historia del Perú de Carlos Wiesse desde su primera edición y las sucesivas, en esencia es un Resumen de la Historia del Español en nuestras tierras y de los criollos que, luego de la Independencia, se sucedieron en el poder de un gobierno para el cual los indígenas no tenían ninguna participación. Lo mismo ocurrió con otros textos de este autor, por lo menos hasta 1937, repitiéndose el mismo esquema segregacionista y excluyente. Aunque debemos reconocer a Wiesse como un ser de su tiempo, y por lo tanto producto de la ideología imperante, no es menos cierto que sus primeros textos escolares realizados en el Perú de fines del siglo XIX y principios del XX, no tuvieron un fin integrador, por el contrario se desvalorizó al peruano de ascendencia indígena tildándolo de conformista, apático y falto de higiene, y atribuyendo a una condición biológica su aparente pasividad. Las imágenes incorporadas que definitivamente llamaban la atención a primera vista, y que de seguro fueron más rápidamente asimilables que los textos, correspondieron a la visión sectaria y excluyente del propio autor; en ese sentido dichas láminas no fueron ingenuamente escogidas. Existiendo imágenes que mostraban una visión favorable a este 
sector mayoritario de la población, Wiesse prefirió obviarlas al parecer por el peligro de acercarlos a su propio concepto de civilización.

Las láminas seleccionadas llevaban y trasmitían una carga ideológica dirigida a exaltar al criollo y a menospreciar al indígena. Sólo hubo identificación por algunos logros de nuestros antepasados prehispánicos pero con reservas; se prefirió mostrar los hechos pero no a quienes lo concretaron.

De este modo, la visión del niño instruido durante más de tres décadas se formó con un concepto negativo respecto a sus connacionales. Aprendió a reconocer y valorar al Perú antiguo, pero no podía comprender que los descendientes de aquellos primitivos peruanos fueran sus pares.

Dentro de este esquema desvalorativo y sistemáticamente aprendido y repetido durante años, era fácil prever que una gran parte de nuestra población no tuviera ninguna participación en la organización del estado, y que viera a éste con razonable desconfianza.

Ante su entorno social, Wiesse legitimó la desigualdad y la sustentó con falsas y maniqueas afirmaciones acerca de la condición sub desarrollada, per se, de las mayorías indígenas.

Es entendible entonces que la situación de analfabetismo, atraso y miseria, perdurara con muy pocos avances durante décadas; los gobernantes instruidos desde su niñez con estas imágenes y textos primigenios fueron (de) formados conscientemente.

Gonzalo Portocarrero y Patricia Oliar desde el análisis de los textos escolares, y a pesar de no analizar ninguna de las láminas consignados en los libros escolares, ni reconocer su primera y fundamental impresión en la mente infantil, llegan a las mismas conclusiones a las que hemos arribado; así se puede corroborar en su texto El Perú desde la Escuela. Sobre este punto, concluyen:

Quizás el hecho decisivo sea que Wiesse escribe, como se ha visto, en una época en que la extensión de la escuela hacia el indígena comenzaba a ser una realidad y no una simple intención, como lo fuera antes. Al ampliarse la cobertura educativa y llegar ésta al indio era conveniente para los grupos dominantes subrayar la importancia de las jerarquías sociales, tanto para legitimar su situación ante sus propios ojos, como también para evitar una visión igualitaria del Imperio que podría suscitar comparaciones desfavorables para la situación del Perú contemporáneo. (Portocarrero y Oliar, 1989 , pp. 51 y 52 )

Está claro que varias generaciones de peruanos de inicios del siglo XX recibieron una visión deforme de la realidad nacional, y que las imágenes que vieron en sus textos escolares calaron en su mente creándoles una (in) conciencia nacional.

Diferente fue el caso de Maria Rosay, hasta hoy un personaje desconocido en la historia de la educación peruana y que nuestra investigación pretende rescatar. Su influencia es de seguro enorme y valiosa a pesar que nadie aún lo ha reconocido. Sus imágenes y sus escritos reflejan el aprecio que tuvo por el Perú, y de seguro ella colaboró positivamente en la creación de una conciencia nacional que partía de reconocer y de mirar con aprecio nuestro pasado milenario. 


\section{Notas}

1. Gil de Castro realizó tres retratos : dos de ellos se encuentran en Perú y el tercero en Venezuela.

2. "El sombrero de Túpac Amaru", En: Túpac Amaru \# 3, órgano de la Dirección de Promoción y Difusión de la Reforma Agraria, agosto-setiembre de 1970, p. 8. Para mayor referencia consúltese el libro El verdadero rostro de Túpac Amaru de Leopoldo LitumaAgüero, Lima 2011

3. Carlos Wiesse Portacarrero nació en Tacna en 1859 y murió en Lima en 1945.

4. En 1868 Mariano Felipe Paz Soldán había publicado el primer tomo de su Historia del Perú Independiente, pero éste sólo trataba la historia patria desde la emancipación, es decir se narraban tan solo cinco décadas, y no contenían ningún dibujo o grabado. Sin ilustraciones también fue el caso de las Lecciones de Historia del Perú, que Elvira García y García publicó en 1894. También tenemos conocimiento de un texto para escolares de Enrique Benites, Curso de Historia del Perú, de 1873, sin embargo no se ha podido ubicar ningún ejemplar en las bibliotecas Nacional, de la UNMSM, ni de la PUCP.

5. El trabajo sociológico de ambos investigadores incluyó: la revisión de textos de Historia, la visita a 59 colegios, entrevistas a 68 profesores y encuestas a 1690 estudiantes.

6. María Rosay pertenecía a la familia dueña de la célebre Librería Francesa y Casa Editora E. Rosay, la cual publicó muchos textos desde fines del siglo XIX, entre ellos los libros de Carlos Wiesse.

\section{Bibliografía}

Cronau, R. (1892). América, Historia de su descubrimiento desde los tiempos primitivos hasta los más modernos. Barcelona: Montaner y Simón Editores.

Lituma, L. (2011). El verdadero rostro de Túpac Amaru, Perú 1969-1975. Lima: Editorial Pakarina.

Lorente, S. (1860). Historia Antigua del Perú. París: Imprenta Arbieu.

Lorente, S. (1861). Historia de la Conquista del Perú. París: Imprenta Arbeiu.

Marmontel, J. F. (1777). Los Incas o la destrucción del Imperio del Perú. París.

Mayer, A. (2001). William H. Prescott, en El surgimiento de la historiografía nacional, vol III, Univ. Autónoma de México, pág. 449.

Portocarrero, G. y Oliart, P. (1989). El Perú desde la Escuela. Lima: Pontificia Universidad Católica del Perú.

Prescott, G. (1853). Historia de la Conquista del Perú. Madrid: Imprenta y Librería de Gaspar y Roig Editores.

Rosay, M. (1924). Mi primera Historia del Perú. Lima: Librería e Imprenta E. Rosay.

Squier, G. (1877). Peru: Incidents of travel and exploration in the land of the Incas. New York: Harper \& Brothers Publishers.

Wiesse, C. (1899). Resumen de la Historia del Perú. Lima: Librería e Imprenta E. Rosay.

El sombrero de Túpac Amaru, en TUPAC AMARU \# 3, Revista de la Dirección de Promoción y Difusión de la Reforma Agraria, agosto-setiembre de 1970. 
Summary: After Indepence, the building became iconographic indispensable due to the need for education in the country's history from a vernacular perspective. But foreigners were the first to set about the research and compilation of national history from its origins. Those texts, no pictures yet, were used in the emerging nineteenth century Peruvian education.

In the early twentieh century came the first illustrated textbooks, wich incorporated images taken from foreign publications, some with a view of what happened european vision in these lands. Other publications less idealized helped with his drawings and print to the visual history of the country, and when they were incorporated into the books for basic education, helped create a collective imagination.

This paper shows the main sources of iconography that served to educate the school population of the early twentieth century. Research also schows how these primordial images were taken as true in different situations concerning the history of Peru and how these have influenced in the national (un) consciousness; facts corroborated by other sociological research.

Keywords: iconography - imagination - history - basic education - Peru.

Resumo: Depois da Independência, a construção iconográfica se tornou indispensável pela necessidade de educar na história pátria desde um ponto de vista vernáculo. Entretanto, foram estrangeiros os primeiros que se abocaram à pesquisa e compendio da história pátria desde suas origens. Aqueles textos, sem imagens ainda, se utilizaram na incipiente educação peruana do século XIX.

No começo do século XX apareceram os primeiros textos escolares ilustrados, que incorporaram imagens tomadas de publicações estrangeiras, algumas delas como uma visão européia. Outras publicações menos idealizadas contribuíram com seus desenhos e gravados à história visual do pais, e quando foram incorporados aos livros para educação básica, ajudaram a criar um imaginário coletivo.

Este artigo mostra algumas das principais fontes iconográficas que serviram para instruir à população escolar de princípios do século XX. Do mesmo modo a pesquisa mostra como estas imagens primitivas se tomaram como referentes verdadeiras em diversas situações da história de Peru e como estas influíram na (in) consciência nacional; feitos corroborados por outras pesquisas sociológicas.

Palavras chave: iconografia - imaginário - história - educação básica - Peru. 